This PDF is a selection from a published volume from the National Bureau of Economic Research

Volume Title: Governance, Regulation, and Privatization in the Asia-Pacific Region, NBER East Asia Seminar on Economics, Volume 12

Volume Author/Editor: Takatoshi Ito and Anne O. Krueger, editors

Volume Publisher: University of Chicago Press

Volume ISBN: 0-226-38679-1

Volume URL: http://www.nber.org/books/ito_04-1

Conference Date: June 28-30, 2001

Publication Date: January 2004

Title: Banks, Bailout Guarantees, and Risky Debt

Author: Aaron Tornell

URL: http://www.nber.org/chapters/c10198 


\section{Banks, Bailout Guarantees, and Risky Debt}

Aaron Tornell

\subsection{Introduction}

During the last decade several emerging markets have experienced twin currency and banking crises. The blame for these crises has been laid at the feet of the policies that have been implemented since the late 1980s. Critics have charged that financial liberalization and bank privatization have been associated with bailout guarantees, and therefore have led to excessive risk taking and overinvestment that have fueled lending booms, inflated asset prices, and rendered economies prone to crises.

The central theme of this paper is that even if we accept that bailout guarantees are the inevitable consequence of financial liberalization, it does not follow that the liberalization policies were doomed to fail. We will argue that in a world where firms are credit constrained, bailout guarantees can be turned into a growth-enhancing vehicle, provided they are accompanied by the right set of policies. Such policies include those aimed at minimizing incentive problems, including rules that ensure bailouts are to be granted only in the event of a systemic crisis and not on an idiosyncratic basis. Also, an efficient regulatory framework is necessary so that banks will perform their monitoring function properly, and connected lending will not exist.

The reforms of the late 1980s liberalized trade and financial markets in many emerging markets. These reforms also brought a significant reduction in the role of the state in the economy. Suddenly, the future looked much brighter than before, and the private sector much smaller than what was desirable. Unfortunately, legal and judicial reform could not be implemented as easily as the other reforms. As a result, many of the institutions

Aaron Tornell is professor of economics at the University of California, Los Angeles, and a faculty research fellow of the National Bureau of Economic Research. 
that support the provision of external finance in developed economies did not flourish in emerging markets. Large firms in the tradables sector could finance themselves in international markets. However, this option was not open to the majority of firms.

The policy problem then became how to better promote the fast development of the private sector in an environment where external finance to a majority of firms is constrained by internal funds, and where investment is too low relative to investment opportunities. One is tempted to say that if a government had the appropriate information and correct incentives, the optimal policy would be to transfer resources to those in the population with better entrepreneurial skills, and to let them make the investment decisions. Of course, we now know that this is wishful thinking. After many failed experiments of this sort carried out during the last century, we now know that either governments do not possess the appropriate information, or they are too inclined to crony capitalism and rampant corruption.

Since direct made-to-measure government transfers are not feasible, during the 1990s governments had to design second-best policies to foster the development of the private economy, especially in the nontradables sector. In many countries the decision was made to implement financial liberalization, and to privatize the banks and allow them to be the means through which resources would be channeled to the nascent private sector. A by-product (probably an unintended consequence) of these policies was the appearance of implicit bailout guarantees. As we mentioned earlier, excessive risk-taking and lending booms developed.

We will argue that the policies we have alluded to above can be considered second-best-optimal, in the sense that policymakers took sensible and calculated risks to promote rapid growth, and were unlucky. Crises were thus not the inevitable consequences of bad policy but simply bad draws that did not have to happen. They were the price that had to be paid in order to attain faster growth. ${ }^{1}$

In course of making this argument, we wish to emphasize five main points relating both to policies during a boom, and to policies after a crisis. First, bailout guarantees can be a second-best instrument to promote investment in emerging economies. Severe enforceability problems make bank credit practically the only source of external finance for most firms, especially the small ones and those in the nontradables (N) sector. In this environment many profitable investment projects cannot be undertaken because agents are credit constrained. Under some conditions, which we will describe below, bailout guarantees promote investment because they ease these borrowing constraints and provide an implicit subsidy to constrained firms.

1. We would like to emphasize that we will not defend some policy measures that simply mask corruption. 
It is worth emphasizing that in order to have growth-enhancing effects, bailout guarantees must be "systemic," as opposed to "unconditional." The latter are granted whenever there is an individual default, like in a deposit insurance scheme. In contrast, the former are granted only if a critical mass of agents defaults. That is, it is essential that authorities can commit not to grant bailout guarantees on an idiosyncratic basis, but only in case of systemic crisis.

The second main point is that there are two preconditions for systemic bailout guarantees to have growth-enhancing effects: there must be an efficient regulatory framework in place, and the environment must be "risky" (but not too risky). We consider each in turn.

An efficient regulatory framework is needed because in the presence of bailout guarantees it is very important to limit the extent of connected loans and to prevent fraudulent activities on the part of banks. When these conditions are satisfied systemic bailout guarantees have the advantage of using the monitoring role of banks. This ensures that the implicit subsidy will be directed to those firms with profitable projects. More generally, to the extent that there is an efficient regulatory framework, systemic bailout guarantees will not generate the incentive problems that plague directtransfer schemes.

A risky environment is necessary because the subsidy implicit in systemic bailout guarantees can be cashed-in only if there exist some states of the world in which there is a systemic crisis. In the absence of exogenous shocks that bankrupt many agents, there must be endogenous volatility. Lending booms and risky dollar debt can generate this endogenous volatility by making the economy susceptible to self-fulfilling crises. In fact, as a way of allowing risk into the system, dollar debt has the wonderful feature of being a good coordinating device, as it can be observed by others. It follows that if prudential regulation is introduced with the goal of minimizing risk in the banking system, for instance by forbidding $\mathrm{N}$-sector firms to borrow in dollars, then the investment-enhancing effect of systemic bailout guarantees might be blocked.

However, having a risky environment does not mean that a crisis has to happen during the transition path. In fact, the likelihood of crisis must be small, or otherwise systemic bailout guarantees might have the unintended effect of drastically reducing productive investment. If the environment is too risky, firms will not find it profitable to invest in the first place.

In some policy circles it has been maintained that fixed exchange rate regimes make economies more susceptible to crises, among other things because they provide fewer incentives for agents to hedge their debts. The third point we make is that systemic bailout guarantees can induce the adoption of risky debt structures in fixed as well as in flexible exchange rate regimes. Guarantees may appear under different guises and need not be explicit. The precise form the bailout takes will depend on the regime. For 
instance, under fixed rates the bailout rate is mostly determined by the amount of reserves authorities are willing to use in order to defend the currency. In contrast, in a pure floating regime the bailout may take the form of direct transfers to agents.

Should an economy experience a bad draw while following policies to promote rapid growth, there is a question about how policymakers should react. This leads us to the fourth point. In the event of a crisis the amount of nonperforming loans increases dramatically. If the bad loans are recognized, the most likely outcome is that the government will have to take over the banking system, make a once-and-for-all bailout payment, and incur a huge fiscal cost up front. This will increase government debt and probably interest rates. On the other hand, if just a small share of nonperforming loans is recognized, the up-front bailout and fiscal cost will be low. However, this strategy might lead to evergreening and generate perverse incentives. Over time the problem might grow and the credit crunch may last longer, as the experiences of Japan and Mexico have shown.

Finally, in the aftermath of crises, countries experienced severe credit crunches. Bailing out lenders and cleaning the balance sheets of banks is not sufficient to reactivate the economy. Since a crisis wipes out a big part of entrepreneurial wealth, it is necessary to implement policies that permit firms to borrow again. Clearly, there are severe incentive problems associated with direct transfers to firms. Systemic bailout guarantees are a second-best instrument to jump-start the economy. To the extent that authorities can commit not to grant bailouts on an idiosyncratic basis and that the regulatory framework works relatively well, systemic bailout guarantees will be immune to incentive problems.

In the next section we present a short description of the Mexican experience. In section 15.3 we present the conceptual framework. Section 15.4, which is the main part of the paper, analyzes the issues we raised above.

\subsection{The Mexican Experience}

The experience of Mexico during the 1990s illustrates, in a rather sharp way, the dilemma faced by policymakers in the aftermath of reform. It also underlines the importance of distinguishing the differential access to external finance of tradables and nontradables sectors.

In the late 1980s Mexico implemented radical trade and financial liberalization, as well as deregulation and privatization programs. These policy measures generated the expectation of an extraordinary growth in exports after a short transition period. After decades of statism, the private sector was too small and so the relevant policy question was how to promote its rapid growth (as well as the investment in the infrastructure that would provide the services and inputs that the tradables (T) sector would need once the extraordinary future arrived). The decision was made to privatize 
Real Credit from the Banking System

to the Private Sector $(1992=100)$
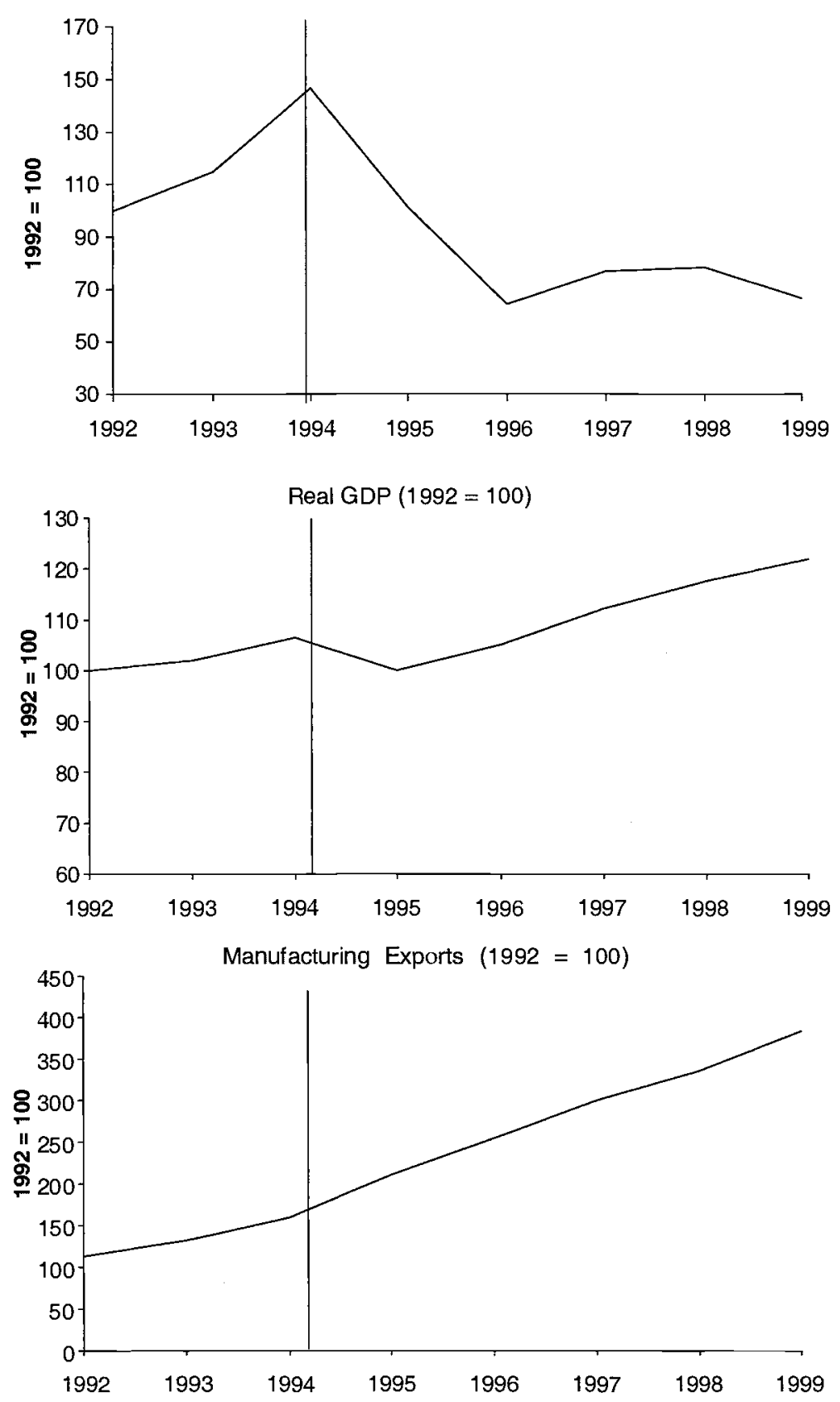

Fig. 15.1 Boom-bust cycle in Mexico

Sources: IMF (2001) and Banco de México.

Notes: Real credit from the banking system to the private sector $(1992=100)$; real GDP (1992 $=100)$; manufacturing exports $(1992=100)$. 

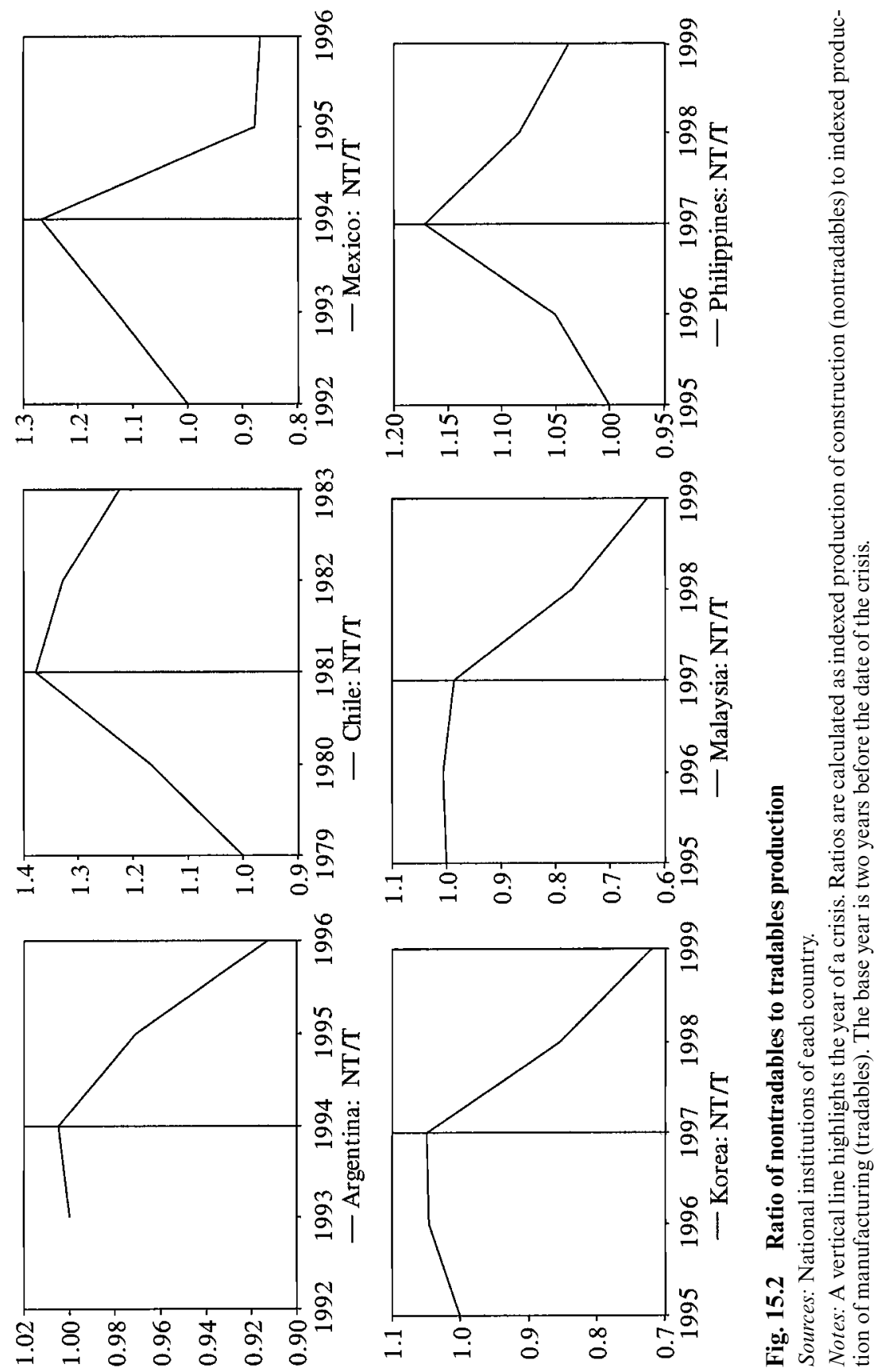

$\ddot{0} \cdot \frac{n}{2}$ 可 可 웡 \& 类 递疍

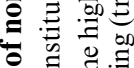
㷎 芯

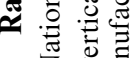

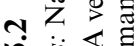
10 过 क⿺辶े 

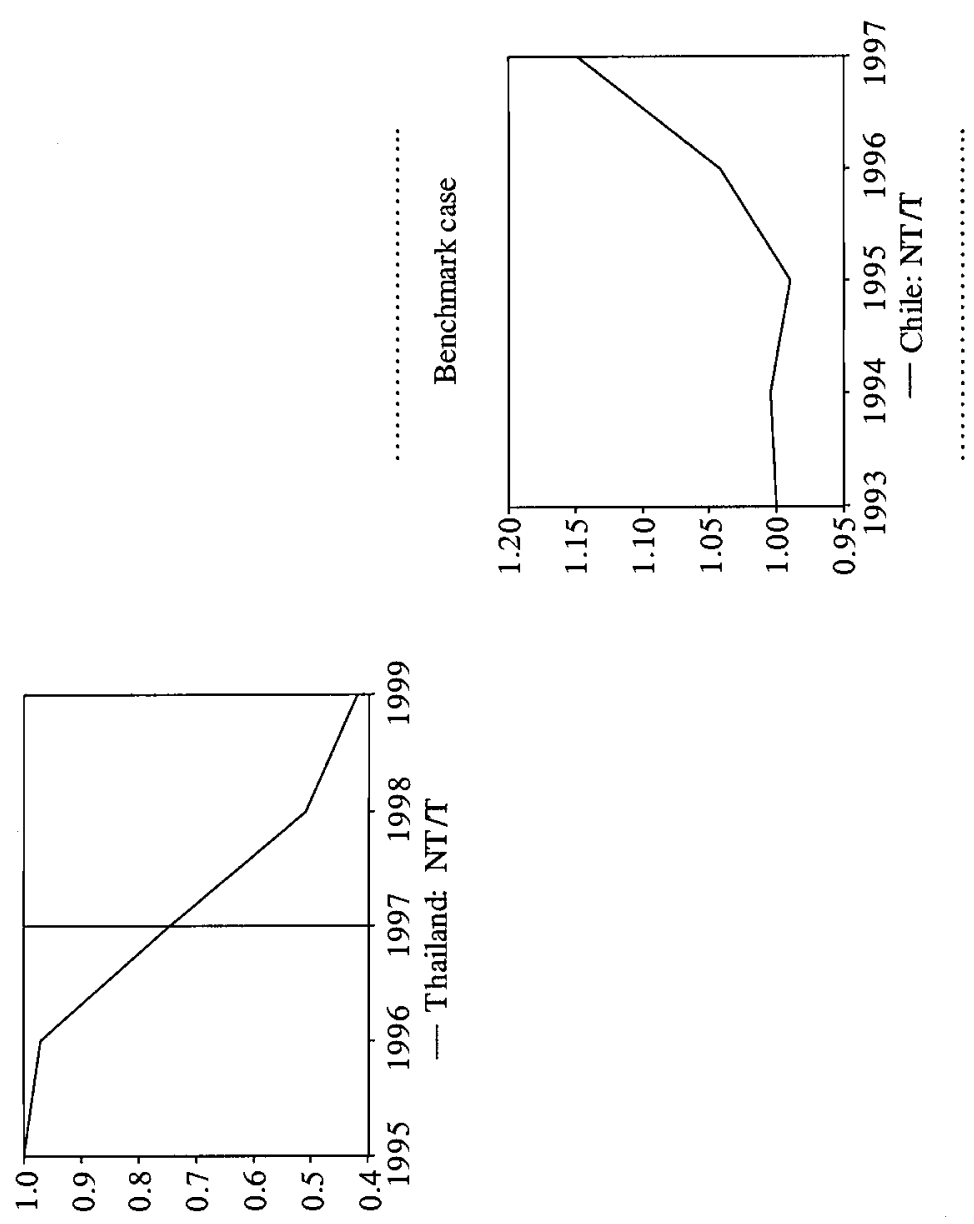

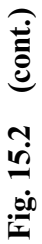



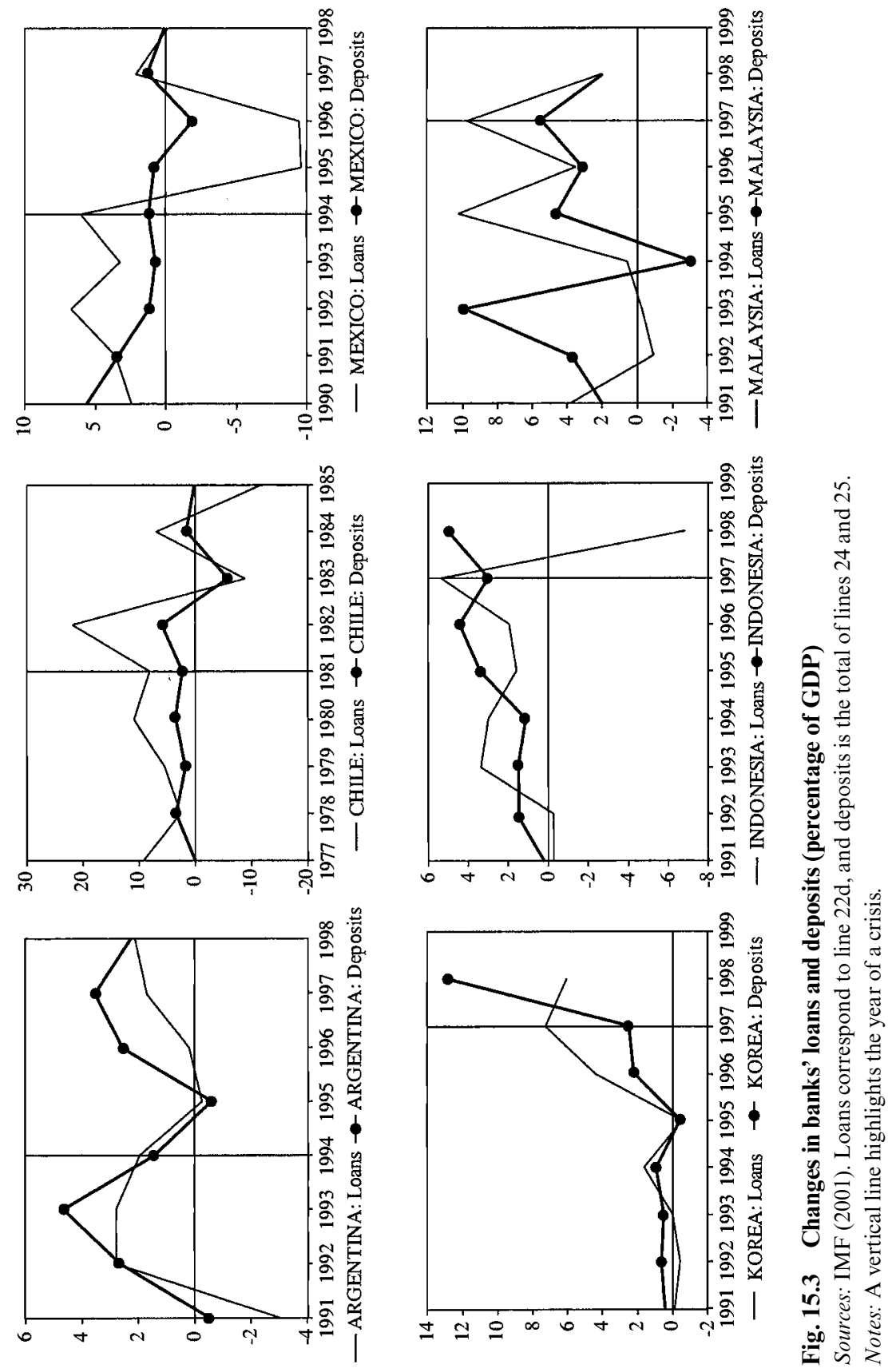

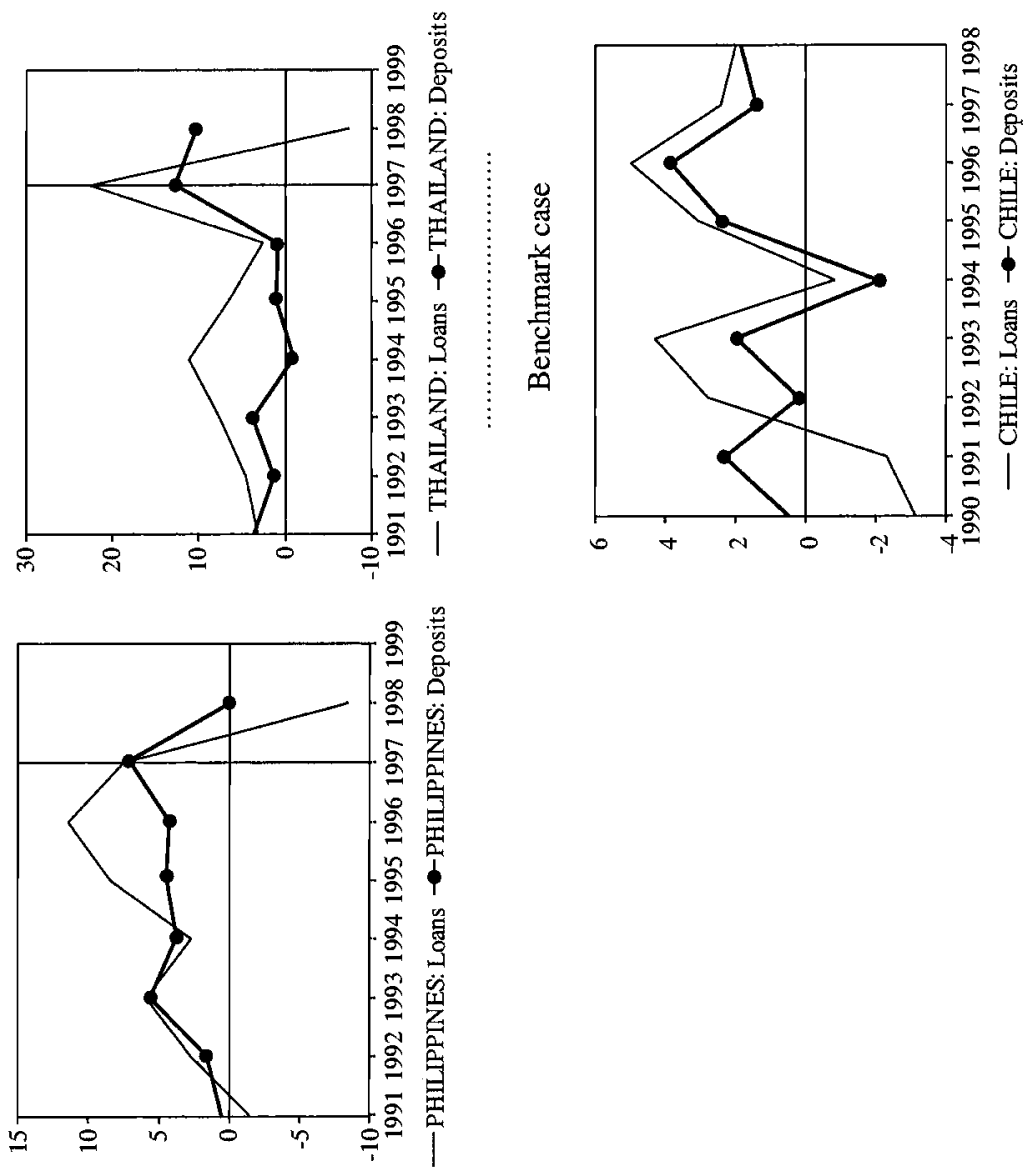

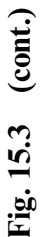


the banks and allow them to be the means through which resources would be channeled to the nascent private sector.

The expectation of an extraordinary growth in exports, as well as implicit bailout guarantees, generated privatization prices for the banks that were way above standard multiples-to-book value. As is well known, Mexico experienced a pronounced lending boom and a severe real appreciation. Between 1992 and 1994, lending from banks to the private sector increased by more than 50 percent in real terms and the real exchange rate appreciated around 15 percent.

In December 1994, the new administration of President Zedillo announced a change in the exchange rate regime and engineered a small depreciation. Although the precrisis estimates of the real appreciation did not exceed 20 percent, Mexico experienced a massive real depreciation of nearly 100 percent. As a result, many firms were unable to repay their dollar-denominated debts and the government had to implement a bailout program, known as the Fobaproa. Current estimates of the Fobaproa's costs are around 20 percent of gross domestic product (GDP).

In the aftermath of the Tequila crisis, real credit from banks to the private sector collapsed and has remained at a depressed level since then (see fig. 15.1). This stands in sharp contrast with the fast recovery of both bank deposits and aggregate real GDP. After a short recession, real GDP started to increase as early as 1996.

Aggregate GDP performance masks an asymmetric sectorial response to the crisis. While the T-sector experienced an acceleration of growth throughout the period, the $\mathrm{N}$-sector experienced a sharp fall and a sluggish recuperation. This asymmetric response was caused by the fact that the credit crunch affected mainly small and medium firms in the $\mathrm{N}$-sector, while firms in the T-sector could obtain finance from international capital markets. As a result, non-oil exports were not affected by the Tequila crisis. In fact, they increased at a faster rate thanks to the real depreciation and to the booming U.S. economy.

The contrasting pattern displayed by the $\mathrm{T}$ - and $\mathrm{N}$-sectors and the credit crunch in the aftermath of crisis is not limited to Mexico. Figure 15.2 shows that in several emerging economies, the ratio of nontradables to tradables production increases before a crisis and declines in the aftermath of crisis. Figure 15.3 shows that typically there is a lending boom before a crisis, and a credit crunch in the aftermath of a crisis. This pattern is consistent with the view that the $\mathrm{N}$-sector is more dependent on bank credit than the $\mathrm{T}$ sector, and is prone to "balance sheet" effects induced by real depreciations. $^{2}$

2. The figures include seven emerging economies: Argentina and Mexico, which suffered a crisis in 1995; Korea, Malaysia, the Philippines, and Thailand, which experienced a crisis in 1997; and Chile, which experienced a crisis in 1982, but did not experience any severe crisis during the 1990s, and so can be considered as a benchmark. 


\subsection{Conceptual Framework}

In a perfectly competitive world several of the policies alluded to in the introduction are welfare reducing. However, to make an appropriate assessment one needs to take into account the context in which policies were designed and the imperfections they were supposed to counteract. The conceptual framework that one uses to evaluate policies should allow for the relevant imperfections, and explain the basic features of the boom-bust cycles that characterize emerging economies. In this paper we will use the model developed by Schneider and Tornell (2000) to make such a policy evaluation.

To explain some of the stylized facts, third-generation crisis models have looked to financial market imperfections as key fundamentals. The models are typically based on one of two distortions: either "bad policy", in the form of bailout guarantees, or "bad markets," in the form of an imperfection that induces balance sheet effects, such as asymmetric information, or the imperfect enforceability of contracts. ${ }^{3}$ Schneider and Tornell (2000) consider an economy that is simultaneously subject to these two distortions: systemic bailout guarantees and the imperfect enforceability of contracts. They also stress the role of the nontradables sector, which is often overlooked in the debate about the causes of recent crises. They show that the interaction of the two distortions generates a coherent account of a complete boom-bust episode.

A simplified version of this model is presented in section 15.3. Here we present an overview. Consider an economy with a tradables (T) and a nontradables $(\mathrm{N})$ sector. In order to explain the facts it is sufficient to consider a simple setup in which $\mathrm{T}$-sector agents are endowed with T-goods, and consume both $\mathrm{T}$ - and $\mathrm{N}$-goods. Meanwhile, agents in the $\mathrm{N}$-sector demand T-goods for consumption, and produce nontradables using only nontradables as inputs according to a linear production technology: $q_{\mathrm{t}}=\theta I_{\mathrm{t}}$.

Firms in the T-sector can easily obtain financing in international capital markets either because they can pledge their export receivables as collateral, or because they are closely linked to firms that can secure their debt. In contrast, firms in the $\mathrm{N}$-sector must rely more heavily on domestic bank credit. N-sector financing is subject to two distortions: enforceability problems and bailout guarantees. High enforceability problems imply that lenders will limit the amount they lend regardless of what the interest rate is. As a result, $\mathrm{N}$-sector agents might face borrowing constraints in equilibrium. In the model, like in several financial accelerator models, the amount of credit available to a firm is determined by the level of internal

3. See Aghion, Bachetta, and Banerjee (1999); Bernanke, Gertler, and Gilchrist (1999); Burnside, Eichenbaum, and Rebelo (2000); Caballero and Krishnamurthy (1999); Calvo (1998); Chang and Velasco (1998); Corsetti, Pesenti, and Roubini (1998); Krugman (1998); and McKinnon and Pill (1998). 
funds. If bailout guarantees are introduced, their interaction with enforceability problems will induce agents to issue risky debt, generating endogenous real exchange rate risk.

In order to explain the fact that in emerging markets debt is often denominated in foreign currency on an unhedged basis, we allow N-sector agents to issue either "risky debt" (denominated in T-goods) or "safe debt" with no real exchange rate risk.

In order to analyze the effect of each distortion we introduce them one by one. Thus, consider an economy in which only enforceability problems are present, as in standard financial accelerator models. If investment has a sufficiently high rate of return, agents will borrow as much as they can. As a result the credit multiplier becomes an investment multiplier:

$$
p_{\mathrm{t}} I_{t}^{\mathrm{s}}=m^{\mathrm{s}}(h) \cdot w_{\mathrm{t}}
$$

where $w_{\mathrm{t}}$ denotes internal funds (denominated in T-goods) of a representative N-sector firm; $p_{\mathrm{t}}=p_{\mathrm{t}}^{\mathrm{N}} / p_{\mathrm{t}}^{\mathrm{T}}$ is the inverse of the real exchange rate; $m^{\mathrm{s}}(h)$ is the investment multiplier which is decreasing in the degree of the enforceability problem (indexed by $1 / h$ ); and $I_{\mathrm{t}}$ is physical investment by the $\mathrm{N}$-sector. Although safe debt is more expensive than risky debt, in the presence of bankruptcy costs issuing safe debt is individually optimal. Thus, in the absence of exogenous shocks, the economy will not exhibit susceptibility to meltdowns. Under no circumstances will firms go bust.

Consider now the second distortion: bailout guarantees. There are two types of guarantees: unconditional and systemic. The former are granted whenever there is a default by an individual borrower (e.g., deposit insurance), while the latter are granted only if a critical mass of borrowers goes bust. Clearly, if all debt were covered by unconditional bailout guarantees, then the enforceability problem would become irrelevant and borrowing constraints would not arise in equilibrium. Since a lender would be bailed out in the case of an idiosyncratic default, the lender has no incentives to limit the amount of credit extended to an individual borrower. Hence, in order for bailout guarantees not to neutralize the effect of the enforceability problem, and for borrowing constraints to arise in equilibrium, it is necessary that some part of banks' liabilities be covered only by systemic bailout guarantees.

Systemic bailout guarantees provide an implicit subsidy that eases borrowing constraints. However, this subsidy can be cashed in only if there are some states of nature in which a critical mass of borrowers goes bust. In the absence of exogenous shocks that bankrupt a critical mass of borrowers, the introduction of systemic bailout guarantees will have an effect only if there is aggregate endogenous risk. In our economy, this bankruptcy risk is generated if there exists enough real exchange rate volatility. In this case, the presence of systemic bailout guarantees induces N-sector agents to issue T-debt. This allows agents to reduce the expected value of debt repay- 
ments. This reduction, in turn, permits agents to borrow more at each level of internal funds. Therefore, at a given point in time, the "investment multiplier" is greater than that of an economy that features only enforceability problems $\left(m^{\mathrm{s}}\right)$. The value of investment by the $\mathrm{N}$-sector is

$$
p_{\mathrm{t}} I_{\mathrm{t}}=m^{\mathrm{r}}(h, F) \cdot w_{\mathrm{t}}, \quad m^{\mathrm{s}}(h)<m^{\mathrm{r}}(h, F),
$$

where $F$ stand for the generosity of the bailout guarantee. We now turn to the question of what is the mechanism that generates endogenous risk.

\subsubsection{Endogenous Real Exchange Rate Volatility}

The first main result is that the interaction of systemic bailout guarantees and enforceability problems can generate aggregate endogenous risk. This is because there is a self-reinforcing mechanism at work. If there is sufficient real exchange rate risk, it is individually optimal for an N-sector agent to issue risky T-debt (i.e., to borrow in foreign currency on a shortterm and unhedged basis). However, if many $\mathrm{N}$-sector agents gamble by denominating their debt in T-goods, exchange rate risk might be endogenously created, as the economy becomes vulnerable to self-fulfilling meltdowns. If the amount of T-debt is high, a real depreciation can severely squeeze cash flow, or even bankrupt banks altogether. Since they face binding borrowing constraints, they then have to curtail lending to the $\mathrm{N}$ sector. Weak investment demand from the $\mathrm{N}$-sector for its own products in turn validates the real depreciation. The systemic credit risk created by the banking system thus induces endogenous exchange rate risk. ${ }^{4}$

To see why real exchange rate variability can make risky T-debt cheaper than safe debt, suppose that tomorrow's real exchange rate can take on two values: an appreciated value that leaves every firm solvent, and a depreciated one that makes a majority of N-sector firms go bust. In the presence of full bailout guarantees, risk-neutral lenders are willing to fund T-debt at world interest rates because it will be repaid in full in both states of nature. It will be repaid either by the borrowers in the good state, or by the bailout agency in the crisis state. Second, if the probability of crisis is small and real appreciation in the good state is large, it clearly pays N-sector agents to issue T-debt and gamble with the bailout agency's money. This is because the greater the real appreciation, the greater the portion of the debt burden, measured in terms of nontradables, that is inflated away.

To see under which circumstances the existence of T-debt generates volatility we turn to the determination of the equilibrium real exchange rate $\left(1 / p_{\mathrm{t}}\right)$. This price equalizes aggregate demand with the (predetermined) supply of nontradables: $D\left(p_{\mathrm{t}}\right)=\theta I_{\mathrm{t}-1}$. The aggregate demand for

4. Although there are several ways in which agents can engage in risk taking, risky debt denomination (borrowing in dollars to finance nontradables activities) is a wonderful "coordinating device." Since debt denomination is easily observed, agents can implicitly collude to cash in the subsidy implicit in the bailout guarantee. 
$\mathrm{N}$-goods has two components: the demand by the T-sector, and the demand by the N-sector for its own goods. Since at a given point in time supply is given, the key to having multiple equilibria is a backward-bending aggregate demand curve. This is impossible if $\mathrm{N}$-sector firms have only $\mathrm{N}$ debt. In this case, price changes lead to variations in both firms' revenues and their debt payments. In fact, profits (measured in nontradables) are completely insulated against price movements. The upshot is that as long as firms are solvent, demand slopes downward and there is a unique equilibrium real exchange rate.

Multiple equilibria are possible only if $\mathrm{N}$-sector agents have T-debt. In this case real exchange rate movements affect revenues, but keep the debt burden unchanged. Thus, it becomes important to distinguish between insolvent and solvent firms. For real exchange rates more depreciated than a cutoff level $1 / p_{\mathrm{t}}^{\mathrm{c}}$, all $\mathrm{N}$-firms go bankrupt because revenues do not cover the debt burden. As a result, internal funds collapse. Total demand in this range is downward sloping. In contrast, for real exchange rates more appreciated than $1 / p_{\mathrm{t}}^{\mathrm{c}}$, a further real appreciation is accompanied by a more than proportional increase in internal funds. The reason is that revenues increase while the debt burden remains the same. Equivalently, part of the debt burden measured in terms of nontradables is "inflated away." Consequently, investment demand increases.

It is apparent that if the balance sheet effect is strong enough to make aggregate demand bend backward, as in figure 15.4, multiple market-clearing real exchange rates (and hence self-fulfilling "twin crises") can exist. With identical fundamentals, in terms of supply and debt, the market may clear in one of two equilibria. In a "solvent" equilibrium (point B in fig. 15.4), the price (the reciprocal of the real exchange rate) is high, inflating away enough of firms' debt (measured in nontradables) to allow them to bid

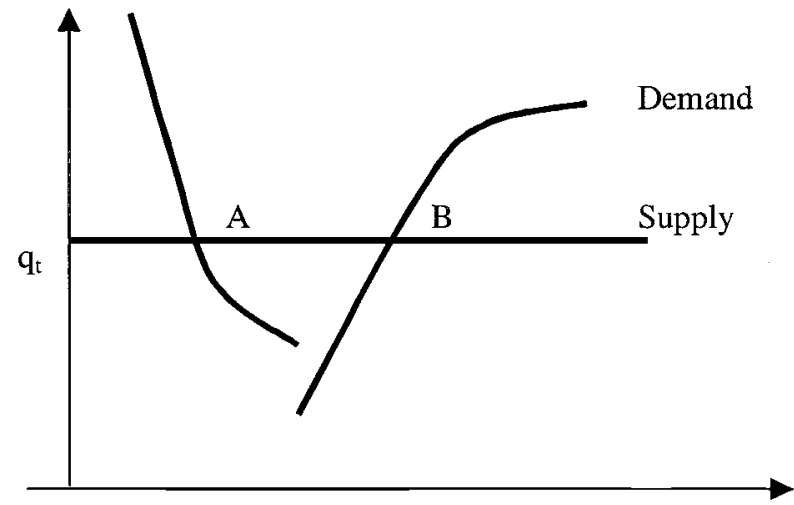

1/[Real Exchange Rate]

Fig. 15.4 Equilibrium in the nontradables market 
away a large share of output from consumers. In contrast, in the "crisis" equilibrium of point $\mathrm{A}$, the price is low, allowing the $\mathrm{T}$-sector and bankrupt $\mathrm{N}$-sector agents with little internal funds to absorb the supply of nontradables. Whichever of these two points is reached depends on expectations. Fundamentals determine only whether the environment is fragile enough to allow two equilibria.

\subsubsection{Equilibrium Dynamics}

The second main result is that the interaction between systemic bailout guarantees and enforceability problems not only induces endogenous volatility, but also fuels the lending and investment booms as well as the real appreciation. This explains the other stylized facts described in the introduction.

As we have seen, systemic bailout guarantees alleviate the "underinvestment" problem. They permit high leverage with debt denominated in Tgoods, and faster credit growth (i.e., $m^{\mathrm{r}} \geq m^{\mathrm{s}}$. As a result, the $\mathrm{N}$-sector grows faster than if guarantees were absent.

Consider now the interplay between the real appreciation and the lending boom. Since $\mathrm{N}$-goods are demanded for investment by the $\mathrm{N}$-sector itself, both output and the relative price of nontradables increase during the boom. Furthermore, since debt is denominated in T-goods, a real appreciation (a relative price increase) reduces the debt burden measured in terms of nontradables. This increases $\mathrm{N}$-sector agents' cash flow. For constrained agents, this translates into more lending through a balance sheet effect. More lending, in turn, permits more investment in $\mathrm{N}$-goods. In order to close the circle, note that if the investment increase is greater than the increase in output, the real exchange rate must appreciate in order to eliminate the excess demand for nontradables.

An economy can follow a risky or safe equilibrium path depending on whether firms' investment plans lead them to go bust in some states. Along the lucky path of a risky equilibrium, credit and investment in the $\mathrm{N}$-sector rise over time while the real exchange rate appreciates. At the same time, demand for $\mathrm{N}$-goods by the $\mathrm{T}$-sector falls. Thus, we have a drastic version of the transfer of resources and the asymmetric sectoral pattern that actually takes place during lending booms. A risky lending-boom equilibrium features two key observed characteristics of credit: debt denomination is used to take on real exchange rate risk and leverage is unusually high. The benchmark is the leverage achieved in a safe equilibrium. The lending boom develops gradually over time. Since the production technology is linear, the relevant "adjustment costs" here are due to the contractenforceability problem. The $\mathrm{N}$-sector can grow only gradually since it must wait for internal funds to accumulate.

A self-fulfilling crisis occurs when the bad state of the sunspot is realized for the first time. The result is a real depreciation and widespread bank- 
ruptcies in the $\mathrm{N}$-sector. This depletes the internal funds of the $\mathrm{N}$-sector. Thus, its investment drops and can only gradually recover (due to the financial adjustment costs mentioned above). At the same time, demand by the T-sector jumps up. Again, this highlights the asymmetric patterns followed by the $\mathrm{N}$-sector and the $\mathrm{T}$-sector.

\subsubsection{Necessary Ingredients for Boom-Bust Cycles}

A key point of Schneider and Tornell (2000) is that the interaction of contract enforceability problems and bailout guarantees creates the fragility required for self-fulfilling crises. If there were no guarantees, firms would not be willing to take on price risk to claim a subsidy. Costly enforceability of contracts alone would still imply that the N-sector can only grow gradually and balance sheet effects would play a role during the lending boom. However, there would be no force impetus to makes the boom end in a crisis. Alternatively, if there were only guarantees but no enforceability problems, then there would not be any balance sheet effects that make demand backward-bending, a necessary condition for a sunspot to matter.

Lending booms that feature fragility cannot occur in just any economy with bailout guarantees and enforceability problems. It is also necessary to have a future increase in the demand of the T-sector for nontradables. Otherwise, the $\mathrm{N}$-sector would not be able to repay the accumulated deficits it runs during the lending boom. Backward induction then indicates that the sequence of returns that supports the lending boom would collapse. This suggests that the boom-bust episodes are more likely to occur during a transition period (for instance, following a far-reaching reform or a natural resource discovery).

Even during a transitional period the likelihood of a self-fulfilling crisis is not a free parameter. If crises were not rare events, either borrowing constraints would not arise, or they would not be binding in equilibrium if they did arise. In either case, credit would not be constrained by internal funds and balance sheet effects would not exist in equilibrium. Clearly, if this were the case, crises could not occur. If the probability of crises is not small enough, enforceability problems do not generate borrowing constraints.

In conclusion, the introduction of systemic bailout guarantees into an otherwise riskless economy can increase the credit and investment multiplier. However, this occurs only if the economy becomes fragile to selffulfilling meltdowns. Systemic bailout guarantees induce agents in the Nsector to switch from safe to risky debt, generating aggregate real exchange rate risk.

\subsection{Policy Evaluation}

An emerging economy is one where the future is much brighter than the present, but where profitable investment projects cannot be undertaken be- 
cause (1) the private sector is small (i.e., entrepreneurial wealth is low) and (2) the amount of external financing is severely limited, especially for firms in the nontradables sector. The reforms of the late 1980s liberalized trade and financial markets in many emerging markets. These reforms also brought a significant reduction in the role of the state in the economy. Suddenly, the future looked much brighter than before, and the private sector much smaller than what was desirable. Unfortunately, legal and judicial reform could not be implemented as easily as the other reforms. As a result, many of the institutions that support the provision of external finance in developed economies did not flourish in emerging markets. Firms in the tradables sector could finance themselves in international markets. However, this option was not open to N-sector firms.

The policy problem then became how to better promote the fast development of the private sector in an environment where external finance to the nontradables sector is constrained by internal funds of firms, and where $\mathrm{N}$-sector investment is too low relative to investment opportunities (e.g., infrastructure, services, etc.). One is tempted to say that if a government had the appropriate information and correct incentives, the optimal policy would have been to transfer resources to those in the population with better entrepreneurial skills, and to let them make the investment decisions. Of course, we now know that this is wishful thinking. After many failed experiments of this sort carried out during the last century, we now know that either governments do not possess the appropriate information, or they are too inclined to crony capitalism and rampant corruption.

Since direct made-to-measure government transfers are not feasible, during the 1990s governments had to design second-best policies to foster the development of the private economy, especially in the N-sector. In many countries the decision was made to privatize the banks and allow them to be the means through which resources would be channeled to the nascent private sector. The issues described in the introduction should be analyzed from this perspective.

We will analyze these issues by using the framework described in section 15.3. Since this model explains many of the stylized facts that characterize the boom-bust cycles experienced by emerging markets during the 1990s, it is an appropriate framework to evaluate the policies implemented by emerging markets. We will argue that when taking into consideration the distortions that exist in emerging markets, there is a sense in which these policies are second-best-optimal instruments to foster the nontradables sector's growth. We would like to distinguish between these policies and those that are designed to mask corruption. The latter are clearly undefendable.

\subsubsection{Policies during a Boom}

Consider the two-sector economy described in section 15.3 in which firms in the $\mathrm{T}$-sector can easily obtain financing in international capital 
markets, while firms in the $\mathrm{N}$-sector must rely more heavily on domestic bank credit. Furthermore, since emerging markets face acute enforceability problems, firms in the $\mathrm{N}$-sector face severe borrowing constraints that limit their ability to undertake profitable projects. As a result, the growth rate of the N-sector is kept below its potential. It follows that a policymaker, whose objective is to maximize social welfare, must design secondbest policies that will ease borrowing constraints and increase investment in the $\mathrm{N}$-sector. Since the $\mathrm{N}$-sector and the T-sector compete for productive resources and since any policies to support the $\mathrm{N}$-sector have implicit fiscal costs, the optimal support level for the $\mathrm{N}$-sector cannot be arbitrarily large.

We have seen that in the presence of severe enforceability problems in financial markets, credit is constrained by internal funds. As a result, profitable investment projects will not be undertaken, especially in the Nsector. Thus, over the medium-run, growth will be significantly lower than its potential. This indicates that systemic bailout guarantees might actually play a socially beneficial role. Systemic bailout guarantees provide an implicit subsidy that reduces the cost at which firms can fund themselves, and that increases the credit multiplier. This increases investment and growth at each level of internal funds. In the absence of better instruments to promote investment and growth of the N-sector, systemic bailout guarantees are a second-best instrument to make transfers to this sector. We would like to emphasize that this mechanism uses the information and monitoring capacity of banks.

Although there are several ways systemic bailouts can be implemented, for simplicity, consider the generosity of bailout guarantees $(F)$ as the policy instrument. An increase in $F$ induces an increase in the investment multiplier in equation (2), which in turn leads to a higher growth rate of the Nsector. Therefore, in an emerging economy it is optimal to set $F$ higher than zero in order to reduce the underinvestment problem. However, there are trade-offs: first, the greater $F$ the greater the contingent fiscal cost; and second, the greater $F$, the greater the share of resources allocated to the Nsector at the expense of the T-sector. Therefore, the level of $F$ should not be set too high. There is an interior optimum.

We would like to emphasize three points. First, systemic bailout guarantees do not curtail the discipline faced by either individual banks or firms because they are granted only if a critical mass of agents defaults. At the same time, systemic bailout guarantees generate an investment subsidy only if the banks' portfolios are risky, that is, only if there exist states of nature in which there is systemic crisis. In the absence of large exogenous shocks, guarantees will be effective in promoting investment only if the banking system generates risk endogenously (we address this issue below). Second, systemic bailout guarantees imply that the government can credibly commit not to bail out individual agents in the case of idiosyncratic de- 
fault. Third, if in a given country banks play no monitoring role and are prone to fraud, systemic bailout guarantees will not be socially beneficial.

The experience of Mexico during the 1990s illustrates, in a rather sharp manner, the policy dilemma faced by reformers. Several critics have pointed to the "false rosy expectations" generated by the government, and the promises of bailout guarantees, as the culprits for the Tequila crisis. Certainly, in hindsight this is true, a policymaker would say. However, at that time it seemed a sensible policy. It was a way to avoid low growth and bottlenecks in the N-sector that would otherwise limit the overall future growth of the economy. Plus, from a political standpoint the development of the private sector encouraged by the policy had the added virtue of creating new power bases that would block attempts by statist groups to go back to the old ways. It was a way to ensure the continuity of the reforms.

An important issue that we have not discussed yet is unconditional bailout guarantees, which are granted whenever an individual debtor defaults. Deposit insurance is a prime example. If all guarantees were unconditional, the discipline in the banking system would disappear and guarantees would not play the investment-promoting role we described above.

However, if unconditional bailout guarantees are granted to small bank depositors, they might play a socially beneficial role. This policy avoids bank runs generated by cascading rumors, but does not impinge negatively on the market discipline faced by an individual bank because small depositors typically have very little information regarding the bank's portfolio. As is the case in the United States, market discipline should be imposed by noninsured bank debt, the interest rate of which should serve as an indicator of a bank's health.

\section{The Role of Risky "Dollar" Debt}

As mentioned above, systemic bailout guarantees have investmentenhancing effects only in the presence of risk. In the absence of large exogenous shocks, some endogenous volatility must be present if the policy is to be effective. Therefore, outlawing risky dollar debt could undo the investment-enhancing effects of systemic bailout guarantees. Thus, if the conditions of a country call for bailouts as a second-best policy to promote the growth of the private sector, then risky debt (or another way to generate endogenous volatility) must also be allowed. Of course, this does not mean that banks should be allowed to have outrageously risky portfolios. It just means that a naive policy of outlawing risky dollar debt is not correct from a normative perspective.

Since systemic bailout guarantees can be cashed only in states of the world in which there is a systemic crisis, systemic bailout guarantees are effective in increasing investment only if a significant part of the economy is vulnerable to systemic crises. It is only during a systemic meltdown that the bailout agency makes payments to lenders. Thus, the expected value of 
the subsidy is determined by the likelihood of a crisis and by the generosity of the bailout. The greater the expected value of the subsidy, the lower the interest rates that lenders are willing to accept. Clearly, banks' portfolios cannot be outrageously risky, as the likelihood of crisis must be quite small in order for the mechanism identified in this paper to be operative. Otherwise, firms would not find it profitable to borrow and invest in the first place! Note, however, that small is not the same as zero. In the absence of major exogenous shocks, the fragility must come from within the system. This is precisely the role of risky debt denomination. As we explained above, if a majority of borrowers have unhedged debt, the economy as a whole can become vulnerable to self-fulfilling crises.

As a way of allowing risk into the economy, dollar debt has the wonderful feature of being a coordinating device, as it can be observed by others. It plays the same role as the real estate buildup on an uninsured basis in catastrophe-prone areas. The principle that "if everyone else does it, then I am safe" reigns.

From a positive perspective it is impossible to outlaw dollar short-term debt. Many firms need such debt in order to carry out their international transactions. Since it is impossible to distinguish what part of dollar debt is used by a given firm to finance international transactions, it is not feasible to enforce a law that forbids dollar debt for uses other than international trade. This lesson has been painfully learned by many countries that have tried to implement dual exchange rates, and then were faced with rampant mis-invoicing of imports and exports.

In conclusion, the degree of banks' and firms' portfolio riskiness should be strictly regulated. However, risky debt should not be outlawed altogether. It is neither socially optimal nor practically implementable.

\section{The Role of Lending Booms and Asset Price Inflation}

During a lending boom credit grows unusually fast and, as many observers have pointed out, monitoring effectiveness declines. Thus, it is less likely that unprofitable and white elephant projects will be detected and stopped. At the same time, firms in emerging markets have a very low level of external finance, especially in the $\mathrm{N}$-sector. Thus, a lending boom is a mechanism by which faster growth can be attained. In fact, the lending boom is a transitional phase that is ignited by deep economic reforms that make the future much brighter than the present.

Stopping a lending boom - for example, by increasing reserve requirements - would interrupt the policy of promoting the growth of the private sector. However, allowing the lending boom to continue unchecked increases the debt burden of the economy, which makes it more vulnerable to crises. Hence, it is not clear ex ante at which point a lending boom should be stopped.

It is interesting to note that although crises typically are preceded by 
lending booms (Tornell 1999), the converse is not true. Gourinchas, Landerretche, and Valdes (1999) find that for a large panel of countries the probability that a lending boom ends in a crisis is quite small. That is, in the majority of cases, lending booms end with soft landings. Furthermore, theoretically lending booms can develop only if the probability of crisis is small and they are expected to end with a soft landing if they last long enough (see Schneider and Tornell 1999).

Clearly, India has not experienced lending booms of such magnitude as the ones experienced by Korea. Moreover, India has not suffered currency crises as deep as those endured by Korea. Certainly, this does not mean that over the last half-century the Indian economy has performed better than Korea's. Of course, with hindsight, Korean performance could have been improved on the margin. However, we should beware of fine-tuning policies designed (ex post) to look great ex post.

Prior to several crises it has been observed that some assets, such as real estate, experience a steep price inflation that is followed by a price collapse at the time of crisis. Since real estate is used as collateral, there is a close link between lending and asset price inflation during a boom. Thus, implementing policies that would stop asset price inflation will also reduce the growth of credit. Clearly, it might be dangerous to leave asset price inflation unchecked. However, some degree of inflation might be desirable as a tool to ease borrowing constraints. ${ }^{5}$

\section{What Are the Effects of Reforms That Improve the Contracting Technology in Financial Markets?}

During the last decade several countries privatized their banks, liberalized their financial markets, and implemented legal reforms that facilitated contracts between private agents. Unfortunately, in several cases these reforms have lead to an increase in fraud instead of economic growth (see Tornell 2000). The lack of a concurrent improvement in prudential regulation is often cited as responsible for this lackluster outcome. Given that the regulatory framework cannot be improved by decree, the question arises as to whether such reforms should be implemented regardless of the regulatory framework.

To address this issue it is important to note that there is a nonlinearity in the relationship between the degree of contract enforceability and the desirability of financial-sector reforms. We will argue that such reforms are socially beneficial only if contract enforceability is very low, or the reforms are radical enough so as to eliminate balance sheet effects.

An improvement in the financial markets' contracting technology has the effect of increasing credit at each level of internal funds. In terms of

5. Schneider and Tornell (1999) study the interplay between asset prices and lending along a boom. 
equations (1) and (2), it means a reduction in the parameter $h$ and an increase in the investment multipliers $m^{\mathrm{s}}$ and $m^{\mathrm{r}}$. In the extreme, if contracts are not enforceable and the legal system is nonfunctional, it will be almost impossible for creditors and lenders to establish a bilateral debt agreement. With certainty borrowers will divert funds and default. As a result, credit to the $\mathrm{N}$-sector will be almost nil, and the economy will not be fragile to crises. In this environment the introduction of systemic bailout guarantees would obviously not induce greater investment as suggested in the previous section. Thus, in these extreme circumstances privatization of the banking system and reforms that improve the contractual environment are clearly socially beneficial.

Consider now the other extreme, in which it is possible to implement legal reforms that reduce the enforceability problem to such a level that it is possible for even small firms in the $\mathrm{N}$-sector to enter into bilateral agreements with foreign lenders. Clearly, in this extreme case borrowing constraints will not be an issue. As a result, firms could borrow up to the level determined by profitability and technological conditions. Therefore, it is socially beneficial to bring the enforceability of contracts to a level where the majority of domestic firms and banks do not face borrowing constraints. Moreover, if this were the case, there would be no role for systemic bailout guarantees. Even if they were put in place, they would be irrelevant!

But, what if contract enforceability $(h)$ is at an intermediate level? Would privatization and financial reforms that improve private contracting unambiguously be socially beneficial? The answer is no. A concurrent improvement in prudential regulation is essential. Recall that it is not socially optimal to increase credit to the $\mathrm{N}$-sector indefinitely at the expense of the T-sector. There is an interior maximum. Taking as given the generosity of bailouts $(F)$, an improvement in contract enforceability $(1 / h)$ eases borrowing constraints and increases the credit multiplier. However, it does not eliminate borrowing constraints and balance sheet effects altogether. As a result, such an improvement in private contracting might induce more fragility than what is socially desirable. Clearly, if one could fine-tune the generosity of bailout guarantees, one could envision some trade-off. Unfortunately, systemic bailout guarantees are more often than not determined by political forces. Either you have them or you do not!

Another way of stating this argument is that, after some point, a further improvement in contract enforcement will only serve to permit borrowers and lenders to better collude in ripping off the bailout agency and taxpayers. Instead of enhancing the rate of growth of the economy, it will simply facilitate the adoption of white elephant investment projects that mask theft, or might make it easier to design fraudulent lending schemes. If not accompanied by improvements in the regulatory framework, reforms that simply improve contractual arrangements marginally might have the unintended effect of fostering crony capitalism. 


\section{The Role of Prudential Regulation}

Our previous discussion highlights the need to improve prudential regulation concurrently with privatization and financial reforms. There are two levels at which the regulatory body should act. First, it should ensure that the banking system does not undertake more risk than what is socially desirable. As we discussed in the previous section, a risky debt profile might be necessary for the subsidy implicit in systemic bailout guarantees to have the desired effect of increasing credit and investment. However, this does not mean that anything goes. Appropriate regulation must determine the financial ratios in accordance with the situation of a given country. Blindly applying the Basel accord requirements does not make sense, as the level of risk induced might be greater than the one appropriate for the country in question.

The second level at which the regulatory body should act is in minimizing the extent of fraudulent schemes and adoption of white elephants. The more efficient the regulatory agency is in blocking these manifestations of crony capitalism, the more likely that systemic bailout guarantees will induce fast and sustainable economic growth, and the greater the social payoff associated with reforms that improve contractual enforceability. In the absence of a strong and independent regulatory agency, it becomes important to consider whether the ownership of banks should be strictly separated from ownership of industrial corporations. We will discuss this below.

Reforms that permit better bilateral private contracting should go hand in hand with improvements in regulatory capacity. However, it seems that here lies one of the greatest bottlenecks faced by emerging markets. More often than not, regulatory agencies fall prey to those they regulate. We now know that this is a political distortion that cannot be eliminated by decree.

In the case of banks, at the time of privatization a significant part of de facto nonperforming loans are passed on to the new owners. These invisible nonperforming loans reflect typically past hidden fiscal deficits or political payoffs. At the time of privatization it is politically expedient not to recognize them, and pass them on to the new owners. This has two implications. First, the true capitalization of the newly privatized banks is lower than what the standard ratios indicate. Second, if the privatizers are also the regulators, there is a strong reason for regulators to oversee some future malpractices of the banks: bankers help regulators hide some nonperforming loans to begin with. Both implications make it more likely that the recently privatized banking system will engage in excessively risky lending and even in fraudulent activities.

Even if capture of regulatory agencies is not an issue, one still needs to worry about regulatory forbearance and evergreening. Regulators have incentives to consider the negative shocks that hit banks' balance sheets as 
more transitory than what they actually are. Doing so avoids forcing banks to recapitalize. Since banks often fail to do so, authorities must seek fiscal resources to recapitalize banks. Since such actions are politically costly, it is always better to ignore the problem, at least for the time being. Thus, with the acquiescence of regulators, banks capitalize the past due interest of de facto nonperforming loans. These loans now become evergreen accounts. Obviously, this is an explosive situation: the capitalization of banks will have to be confronted in the future. There are more perverse situations where evergreen accounts reflect political favors to specific powerful groups.

The FDICIA law implemented in the United States in 1991 has several elements that might be effective ways to improve the regulatory framework in emerging markets (see Kaufman (1997)). This law makes sanctions to banks mandatory and thus lessens political pressure on regulators. This law includes a prompt-corrective-action clause according to which a bank's problems must be solved before effective capital becomes negative. Sanctions are applied in stages depending on the level of effective capital. These sanctions include restrictions on dividend payouts, limits on assets' growth, and losing management rights. Furthermore, new capital must be injected by owners before effective capital becomes negative. With these measures, the resolution of a bank does not imply fiscal costs. International organizations could focus much more attention on this area.

\section{The Role of Foreign Banks}

During the last decade the share of the domestic banking system owned by foreigners has increased spectacularly. The accepted wisdom is that foreign ownership of banks brings three main benefits to an emerging market. First, foreign banks improve the banking practice and know-how. Second, since the size of the private sector in emerging markets is too small, the existence of foreign banks makes it easier to separate ownership of banks from ownership of industrial corporations. As we discussed earlier, in the presence of a weak regulatory framework this separation might reduce the likelihood of fraudulent schemes between lenders and borrowers.

Third, in case of a systemic crisis, parents of foreign subsidiaries will inject the resources necessary to withstand a run. Note, however, that in general foreign subsidiaries are legally separate entities from the parents. Thus, subsidiaries can declare themselves in bankruptcy during a crisis, without affecting the parent company. Reputation considerations are frequently invoked to defend the notion that resources would be transferred by the parent in case of a crisis. This argument is far from obvious because in case of a systemic crisis all parent banks can refuse to support their subsidiaries (by invoking some sort of force majeure clause), without losing reputational capital vis-à-vis the other major international banks. 


\section{Bailout Guarantees and the Exchange Rate Regime}

There are several ways in which systemic bailout guarantees can be implemented. The particulars will of course depend on the exchange rate regime. A nice feature of Schneider and Tornell's framework is that the effects of guarantees and the forces that generate boom-bust cycles are independent of the exchange rate regime or monetary policy rule. This permits us to study how guarantees affect the economy under different regimes.

With fully flexible exchange rates the mechanism is literally the same as the one we consider in section 15.3. If agents are highly leveraged and have risky dollar debt, the economy is vulnerable to self-fulfilling crises in which there is a severe real depreciation and several agents in the N-sector suffer from balance sheet effects and are unable to repay their debts. As a result, creditors get paid a proportion $F$ of the contracted payment. This bailout payment can be financed by an international organization and/or by an increase in future taxes to the rest of the economy. The real depreciation can arise by either a nominal depreciation, a change in nominal prices, or a combination of both.

Consider the other extreme of a fixed exchange rate regime. In the case of an attack the central bank can defend the currency by either running down reserves or increasing the interest rate. If the attack is successful, the reduction in reserves constitutes a bailout payment to bank creditors that withdraw their funds and convert them into foreign currency. Thus, any defense policy has associated with it a bailout rate $F$. Clearly, the bailout rate need not be 100 percent, as reserves might not suffice to cover all the liabilities of the banking system. We should add that the bailout can be complemented by an explicit transfer, like in Mexico during the Tequila crisis. Again, the real depreciation can come about through a combination of a nominal depreciation and a change in nominal prices.

In the real world we observe a mixture of both regimes. However, it should be clear that the underlying forces are essentially the same in both cases.

\subsubsection{Policy in the Aftermath of Crisis}

\section{Bailing Out Borrowers versus Bailing Out Lenders}

Once a crisis has erupted and a severe real depreciation has taken place, the main objective should be to contain the meltdown and to minimize the number of bankruptcies. This is because inefficient bankruptcy procedures generate deadweight losses. Productive assets are inefficiently liquidated and human capital networks are destroyed. Furthermore, reputational capital in credit markets, which takes a long time to build, is destroyed (Wyne 2000). 
Typically, bailouts are granted to lenders, not to borrowers. However, bailing out lenders does not save borrowers from being decapitalized and suffering bankruptcy. Therefore, despite the occurrence of generous bailouts, credit crunches have developed in the aftermath of crises during the 1990s. This has been reflected in three regularities. First, depositors' bank runs have seldom been observed in the crises of the 1990s. Second, in the aftermath of crises the growth rate of bank loans has typically remained below the growth rate of deposits. Since the value of collateral collapses, banks shift their portfolios toward others assets such as government securities. Third, the interest rate spread has typically remained above its precrisis level after GDP growth has returned to its trend.

Ex post, extending some type of bailout to borrowers might avoid bankruptcies and ameliorate the credit crunch. This policy, however, might not be possible to implement because the fiscal cost might be enormous. Furthermore, it has perverse incentives effects. First, many borrowers that have the ability to pay might simply refuse to do so. Since it is extremely difficult to distinguish liquid and illiquid borrowers during a generalized crisis, it is basically impossible to implement a borrower-bailout policy that discriminates among different types of borrowers. Second, market mechanisms might be blocked as borrowers and lenders might delay the resolution of certain loans.

\section{Piecemeal versus All-at-Once Bailouts}

In the aftermath of a crisis the share of nonperforming loans increases spectacularly. Both regulators and banks have incentives to underreport the true share of nonperforming loans. This way, bank owners need to inject less capital, and the government needs to spend less fiscal resources up front. In contrast, reporting the true nonperforming loans might force a takeover of several banks by either the government or other banks. As a result, bank owners will lose their franchises, and government officials will face political criticism for their failure to appropriately regulate the banking system.

Thus, bankers and regulators have incentives to "believe" that negative news is more transitory than what it actually is, and to make predictions about the banks' portfolios that are more optimistic than what is warranted by the facts. The effect of this misperception is an evergreening of banks' balance sheets. That is, there is a tendency for banks to classify as performing those loans that are actually never going to be repaid, and for regulators to turn a blind eye to this mistake. The problem with evergreening is that it generally leads to an increase in the share of nonperforming loans over time. This is because interest is not repaid, and because banks have incentives to undertake very risky projects that might have negative expected net present value. Banks might even have incentives to extend outright fraudulent loans. 
Evergreening has two negative effects on the economy as a whole. First, the fiscal cost of the bailout grows over time, and it might even grow faster than GDP. Second, the credit crunch suffered by small nontradables firms will be deeper and more persistent, as banks will have more incentives to engage in risky activities than to lend to firms with low internal funds (Krueger and Tornell 2000 analyze the Mexican case).

The alternative policy is to recognize at once all nonperforming loans. Since it is unlikely that bank shareholders will be able to come up with the necessary capital, the government will have to take over all the liabilities of the banking system. This policy implies that government debt must increase by several percentage points of GDP in a single year. This is politically very costly. However, the evergreening alternative is likely to be socially more costly, as the experiences of Japan and Mexico have shown.

\section{Interest Rate and Exchange Rate Responses to Crises}

In the standard Mundell-Fleming model, when there is a capital outflow the needed improvement in the current account can be attained with a real depreciation and with no output costs. According to this view, a depreciation induces a shift of resources from the nontradables to the tradables sector, and makes the economy more competitive in world markets. As a result, growth resumes quite fast after the depreciation.

The Mundell-Fleming framework and traditional balance-of-payments crisis models are not appropriate for explaining these new boom-bust episodes because the banking system plays no essential role in these models. Once we move into a world in which bank lending is essential, and debt is denominated in foreign currency, the traditional policy recommendation becomes invalid. As we have seen, allowing the real exchange rate to depreciate in order to close the external gap has perverse effects. Since domestic firms have dollar-denominated debt but their revenues are denominated in domestic currency, a real depreciation will make some domestic firms unable to repay their debts, and will bankrupt them. This in turn, will make the problem even worse. Capital flight will increase, the real exchange rate will depreciate even further, and more firms will go bust. This vicious circle will generate a meltdown of the domestic sector of the economy.

In this situation an increase in interest rates might not be such a bad idea. But does it actually work? It is not clear, whether from an empirical or a conceptual perspective. In a sample of seventy-five countries over the period 1960-1997, Kraay (2000) finds no evidence that interest rates systematically increase during failed speculative attacks, nor that raising interest rates increases the probability that an attack fails.

From a conceptual perspective, an interest rate hike is effective in stemming a crisis only if such an increase does not bankrupt a critical mass of firms. If a critical mass of firms goes bust because they are unable to meet their debt service, then the investment demand will collapse and the real ex- 
change rate will have to depreciate in order to clear the market for nontradables. The end result will be the same as the one in the previous paragraph.

In contrast, if an interest rate hike simply generates a recession but does not induce generalized bankruptcies, then an immediate crisis might be avoided. The question then arises as to whether the time of reckoning will not simply be pushed forward. Will higher domestic interest rates simply induce foreign investors to exploit arbitrage opportunities during a short period until central bank reserves are depleted? Will higher domestic interest rates make several firms insolvent, and lead them to bankruptcy in the near future? It is necessary that the answers to these questions are in the negative in order for an interest rate increase to avoid a crisis.

Clearly, the specific situation of a country will determine what is the correct mix of exchange rate depreciation and interest rate increase.

\section{References}

Aghion, Philippe, Philippe Bachetta, and Abhijit Banerjee. 2000. Capital markets and the instability of open economies. Study Center Gerzensee, Switzerland. Mimeograph.

Bernanke, Ben, Mark Gertler, and Simon Gilchrist. 1999. The financial accelerator in a quantitative business cycle framework. In The handbook of macroeconomics, ed. J. Taylor and M. Woodford. Amsterdam: Elsevier.

Burnside, Craig, Martin Eichenbaum, and Sergio Rebelo. 2000. On the fundamentals of self-fulfilling speculative attacks. NBER Working Paper no. 7554. Cambridge, Mass.: National Bureau of Economic Research, February.

Caballero, Ricardo, and Arvind Krishnamurthy. 1999. Emerging markets crises: An asset markets perspective. MIT, Department of Economics. Mimeograph.

Calvo, Guillermo. 1998. Capital flows and capital market crises: The simple economics of sudden stops. Journal of Applied Economics 1 (1): 35-54.

Chang, Roberto, and Andres Velasco. 1998. Financial crises in emerging markets: A canonical model. NBER Working Paper no. 6606. Cambridge, Mass.: National Bureau of Economic Research, June.

Corsetti, Giancarlo, Paolo Pesenti, and Nouriel Roubini. 1998. Paper tigers. New York University, Department of Economics. Mimeograph.

Gourinchas, Pierre Olivier, Oscar Landerretche, and Rodrigo Valdes. 1999. Lending booms: Some stylized facts. Princeton University, Department of Economics. Mimeograph.

International Monetary Fund (IMF). 2001. International financial statistics yearbook [CD-ROM]. Washington, D.C.: IMF.

Kaufman, George C. 1997. Banking reform: The whys and how tos. Paper presented at the EWC/KDI Conference on Restructuring the National Economy, Honolulu, Hawaii, 7-8 August.

Kraay, Aart. 2000. Do high interest rates defend currencies during speculative attacks? World Bank, Research Department. Mimeograph.

Krueger, Anne, and Aaron Tornell. 1999. The role of bank restructuring in recov- 
ering from crises: Mexico 1995-1998. NBER Working Paper no. 7042. Cambridge, Mass.: National Bureau of Economic Research, March.

Krugman, Paul. 1998. Bubble, boom, crash: Theoretical notes on Asia's crisis. MIT, Department of Economics. Working Paper.

McKinnon, Ronald, and Huw Pill. 1998. International overborrowing: A decomposition of credit and currency risks. Stanford University, Department of Economics. Working Paper.

Schneider, Martin. 1999. Borrowing constraints in a dynamic model of bank asset and liability management. University of Rochester, Department of Economics. Mimeograph.

Schneider, Martin, and Aaron Tornell. 1999. Lending booms and asset price inflation. University of California, Los Angeles, Department of Economics. Working Paper.

. 2000. Balance sheet effects, bailout guarantees, and financial crises. NBER Working Paper no. 8060. Cambridge, Mass.: National Bureau of Economic Research, December.

Tornell, Aaron. 1999. Common fundamentals in the Tequila and Asian crises. NBER Working Paper no. 7139. Cambridge, Mass.: National Bureau of Economic Research, May.

2000. Privatizing the privatized. Chapter 5 in Economic policy reform: The second stage, ed. Anne O. Krueger. Chicago: University of Chicago Press.

Wyne, Jose. 2000. Business cycles and firm dynamics in small emerging economies. University of California, Los Angeles, Department of Economics. Mimeograph.

\section{Comment Kyoji Fukao}

Although the major part of this paper is based on a theoretical model, which was originally presented in Schneider and Tornell's (2000) National Bureau of Economic Research (NBER) working paper, the author does not provide substantial explanation of the model in this paper. I found that without reading Schneider and Tornell's working paper, it is very difficult to understand this paper. I would like to ask the author to add sufficient explanation of the background model to this paper.

Let me explain Schneider and Tornell's model, first. Their model is based on two basic assumptions.

First, there are bailout guarantees for systemic risk in the nontradablegoods sector (N-sector). The guarantees make firms choose risky investment plans. The guarantees also work as a kind of investment subsidy.

Second, because of contract-enforceability problems, firms face borrowing constraints. The size of firms' investment is constrained by the amount of their internal funds.

In financial theory, we know these two mechanisms very well. But by combining these two mechanisms and by including several additional as- 
sumptions, Schneider and Tornell constructed a very interesting general equilibrium model.

The additional assumptions are that firms borrow foreign currency in order to make their investment plans risky, and that the real exchange rate is determined by the equilibrium condition in the nontradable-goods market. Multiple equilibria exist in the model. If the domestic currency depreciates, firms in the nontradable-goods sector go bankrupt and investment demand for nontradable goods declines. In this way a self-fulfilling currency crisis occurs. When there is no crisis, the $\mathrm{N}$-sector will gradually grow. This is the essential part of Schneider and Tornell's model.

In this new paper, the author takes the following strategy. He assumes that Schneider and Tornell's model is completely correct and derives several policy implications from it. His main policy implication is, "The introduction of systemic bailout guarantees can increase the credit and investment multiplier," and that it "can be considered second-best-optimal."

I think that the author's strategy is not very successful. When we construct a model, we can use bold assumptions in order to simplify the model. Schneider and Tornell's paper is excellent. But when we write a paper on economic policy, we need to be more careful about the underlying assumptions. I wished the author would consider the applicability of the model to actual economies, providing more evidence.

Let me provide a few examples.

First, it is assumed that international borrowing is used as a device to create systemic risk by small-sized N-sector firms. But it is not clear why firms do not use other macrovariables to create systemic risk. For example, in many countries, including Japan, investments in real estate created systemic risk.

Second, even if the probability of the occurrence of a currency crisis is low, it is too costly for developing economies to intentionally create risk of currency crisis. There are many other, better policies to enhance the growth of the N-sector. The first-best policy would be to reduce enforcement problems through raising penalties on diversions. The government can use tax incentives to promote investment in N-sector, tax T-sector, or subsidize borrowing by $\mathrm{N}$-sector firms. I would like to ask the author to show why no other policy options are available.

\section{Reference}

Schneider, Martin, and Aaron Tornell. 2000. Balance sheet effects, bailout guarantees, and financial crises. NBER Working Paper no. 8060. Cambridge, Mass.: National Bureau of Economic Research, December. 


\section{Comment Sung Wook Joh}

The author observes that banks experiencing losses cut credit lending during the economic crisis. Moreover, he notes that the crisis credit crunch affected small and medium-sized firms more than it did large firms. When banks experience losses, there are two major ways of dealing with them: (1) market-based approaches and (2) regulatory authority bailouts. Tornell tries to link bailout policies to an effort to mitigate the credit crunch and avoid underinvestment by small firms. He argues that policymakers can induce banks suffering losses to lend money to small firms producing nontradable goods by giving them bailout guarantees.

This paper provides a different perspective on the currency crisis. Tornell argues that emerging economies pursuing faster growth inevitably risk currency crises. More details on the relationships among exchange market fluctuation, credit lending, and growth would improve this argument.

When a crisis occurs, Tornell argues, credit crunching yields different impacts over different industries and different sectors. His figures show that the ratio of nontradables to tradables production falls in many countries after the crisis. In figure 15.3, he also shows that the percentage of bank loans and deposits over gross national product (GDP) changes after the crisis. More evidence supporting a mechanism by which the credit crunch directly causes a drop in the ratio of nontradable goods to tradable goods would improve this argument.

This paper does not suggest a mechanism to ensure that banks receiving bailout guarantees will lend money to the target firms. Banks can lend money to larger firms rather than small firms. As banks become more cautious on their lending after the crisis, they are likely to be more concerned about the credit risk of borrowers. In general, small firms do not have a strong credit history, so they often lack credit accessibility. Thus, a mechanism that connects bailout policy and lending to small firms is necessary.

Tornell argues that an efficient regulatory framework and a reasonably risky environment are necessary for a successful systematic bailout policy. There are several other factors to consider regarding the government's bailout policy, including (1) adequate fiscal means, (2) bailout size, (3) bailout coverage, and (4) gradual or one-time bailouts. First, does the government or the regulatory authority have sufficient fiscal means for a systemic bailout? If not, what is the next best option? Second, how much money should be given in bailout guarantees for banks to lend to small firms? Without transparency in bank accounting and a well-functioning corporate governance system, measuring the magnitude of banks' losses is difficult. In Korea, after the government initially bailed out banks with 
losses, the banks reported new losses and asked for more money. Third, should the bailout program be applied selectively to stronger banks or comprehensively to all banks? In Korea, the government closed down five banks and rescued the rest. Would rescuing all the banks have been better? Fourth, should the bailout occur gradually or at one time? Should the government link improved bank behavior to a gradual bailout?

Incentive problems occur when lenders and borrowers anticipate government bailouts of banks suffering losses. Banks may exacerbate losses to induce government bailouts. Instead of reporting losses early, banks can wait until the losses become large enough to require the government's intervention. Moreover, lenders might allow weak firms to borrow more money to provoke a crisis.

In Korea, large business groups (chaebol) are a critical mass of the economy. The failure of a few chaebol would trigger systemic bailouts. When chaebol suffered large losses, the government did not want to risk economic contraction and high unemployment. Thus, the government repeatedly gave favorable bank loans to chaebol experiencing losses. Lenders and borrowers then believed that large firms were too big to fail. Borrowers had an incentive to increase their size (e.g., through cross-debt payment guarantees, creative accounting, etc.). When these firms borrowed enough money, they enjoyed a bailout safety net and no longer needed to pursue profit maximization to survive. 